\section{The Importance Of Authentic Materials In Increasing The Effectiveness Of Teaching Foreign Languages: In The Example Of Teaching English}

Xodjimuratova Malika Valievna, Umarxo'jaeva Hilola Sirojiddinova

Assistant of the Faculty of Foreign Languages, Tashkent University of Information Technologies named after Muhammad al - Khorezmi, Uzbekistan

\author{
G OPEN ACCESS \\ The American Journal of \\ Social Science And \\ Education Innovations \\ JULY 2020 \\ Page No.: 376-379 \\ Volume-II Issue-VII \\ PUBLISHED: 31 JULY 2020 \\ www.usajournalshub.com/inde \\ x.php/tajssei \\ Copyright: Original content \\ from this work may be used \\ under the terms of the \\ Creative Commons Attribution \\ 4.0 licence.
}

\begin{abstract}
Improving the students' communicative competence in the teaching of foreign languages is one of the important tasks of modern pedagogy. The purpose of this article is to promote the effectiveness of teaching foreign languages on the basis of the communicative language teaching (CLT), as well as to increase the communicative competence of the student in English using authentic materials.
\end{abstract}

Keywords: authentic material, GTM, CLT, linguistic competence, communicative competence, pragmatic competence.

\title{
Introduction
}

A modern foreign language must constantly keep pace with the times, work on himself, constantly search for, introduce new methods and technologies into the learning process, in short, skillfully use innovative teaching technologies to increase the effectiveness of teaching. Educational technology is the organization of these learning processes at a high level of skill, art. Professor H. Ibragimov noted that educational technology is focused on the activities of students, taking into account the individual and joint activities of students with the teacher, creating the necessary conditions for independent learning of educational materials(1). Clearly, choosing the right teaching materials is one of the keys to a teacher's success. This trend is particularly 
evident in the process of teaching foreign languages.

It is well known from history that in the 16th century, Latin and Greek were first taught in Europe using the Grammar Translation Method (GTM). GTM aims to develop students' linguistic competence by teaching grammatical structures, words and phrases, and translating texts directly into their mother tongue. At the heart of this style is the teacher, who is always active, explaining grammatical rules, sentence structure, and giving special exercises that include synonyms and antonyms to reinforce the topic, translating texts into the mother tongue. In other words, in grammar translation classes, students learn the language by heart.

Given that the basis of the language is grammar, GTM is very convenient for learners studying a foreign language for a specialty. However, today, due to the demands of the time, the method of communicative approach is much more effective for people who prefer to study foreign languages as a second language.

Communicative language teaching (CLT) is one of the modern methods, unlike GTM, which focuses on the learner. While promoting CLT as a foreign language, CLT allows its students to communicate in the target language they are learning. As Larsen-Freeman (2000) points out, the CLT recognizes communicative competence as the primary goal, while recognizing the interdependence of language and communication.

\section{Materials and methods}

The importance of communicative competence in the learning process is incomparable. This includes not only learning the grammatical rules of the language, but also learning how to use the language correctly, depending on when, where and with whom you are communicating. According to Ahmed \& Pawar, communicative competence is "the ability to communicate." This competence can be oral, written or non-verbal, provided that the student knows the language and has the skills to use it for communicative purposes in real life.

It is obvious that language and communication are closely related. This means that when learners learn a new language, they need to learn how to communicate in that language or how to use it properly. It follows that the teaching materials selected for the CLT are also authentic and should be able to engage students in a conversation in order to achieve better results than language practice.

Different scholars have different interpretations of the term "authentic material." For example, Tomlinson believes that authentic material is designed to communicate more than to teach. In the CLT approach, such materials are taken from real-life situations and brought into the classroom without any modification. Speller argues that authentic material offers a true language that is semantically rich and culturally significant. Catherine T. He used the words "real" and "natural" as synonyms for the term authentic, and the words "artificial" and "unnatural" as antonyms. It follows that authentic materials are real and natural means of communication created by the native speaker of this language, but not specifically designed for use in the classroom, but that can be used in real life. These include newspapers, magazines, music, movies, restaurant menus, prescriptions, various advertising blocks, and more. we can enter. Here are some examples of topics that can be used in such materials:

RECIPES For example, in the syllabus, students are given ordinal and cardinal 
numbers, their differences and applications, and quantification. For this lesson, the teacher can easily use any available source of cooking recipes. This can be done by using video or audio clips, books, newspapers or magazines, or even television and radio broadcasts of the cooking process. This is because the cook naturally uses ordinal numbers, numbers to indicate the number of products and, of course, quantitative indicators to indicate the sequence of food ingredients. In addition, the selected material will serve to increase the vocabulary of the reader associated with the names of food. In particular, it is the most convenient way to engage a female audience in a conversation while attracting the attention and interest of the audience.

It is very convenient and effective to cover the topic of imperative mood in grammar through ADVERTISEMENTS. GTM teachers teach command writing in three different sentence forms, through structure. However, CLT teachers also develop students' pragmatic competence (the ability to interpret and convey meaning in a social context) by teaching them to use commands in a variety of ways through advertising. This is because the command words used in advertisements are structurally similar and are used in different senses. For example, in all of the following advertisements, the command phrases are grammatically identical,

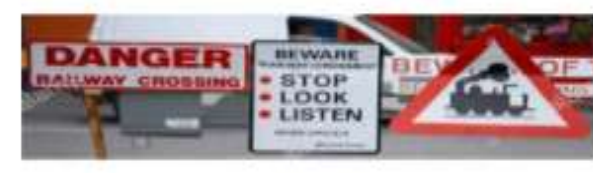

1 - pacm

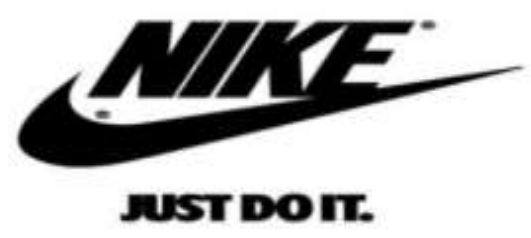

2-pacm

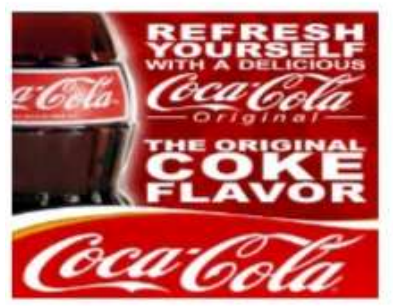

3 - расм

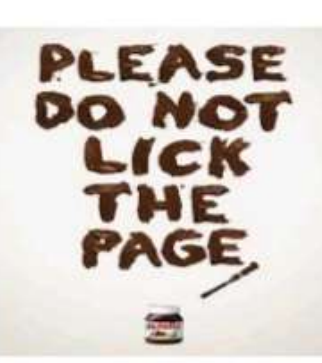

4 - pacm

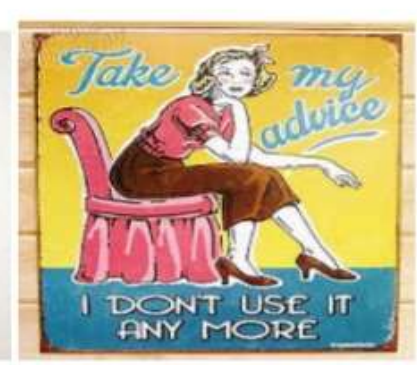

5 - pacm

In the announcement in Figure 1, a one-word command is in the sense of a warning; 2 - in the sense of a command in the picture;

3 - in the sense of persuade with colored words in the picture;

4 - in the sense of a gentle request in the picture;

5 - in the sense of advice in the picture;

This is especially true if the advertisements selected for the training are in audio or video form. This is because the teacher helps the students to develop the skills of pronunciation in the right tone (intonation) depending on the meaning of the command statements through commercials depicting real situations. It is well known that the ability to choose the right tone in a conversation is one of the most important means of 
conveying ideas correctly and clearly.

MOVIES. If the teacher chooses the right film material, it can be the key to the success of a volunteer lesson. As an example, let's take the topic of Request in English. We know that depending on the social status (friend, leader, parent, etc.), request forms (formal, informal, gentle, serious, etc.) are selected. Through special excerpts from various films, the teacher can shape the culture and ability of students to socialize comfortably.

\section{Conclusion}

In conclusion, it is not enough to teach grammar alone to be successful in public life. To do this, it is important to develop students' communicative competence using authentic materials, based on CLT. In addition, the successful application of authentic materials in the process of teaching foreign languages is beneficial not only for the compatibility of the selected material and curriculum, but also for the skills and experience of the teacher, as well as the effective selection of teaching materials.

\section{References}

1.Ahmed, S.T.S \& Pawar, S. (2018). CommunicativeCompetence in English as a Foreign Language: Its Meaning and the Pedagogical Considerations for its Development. The Creative Launcher, 2 (6), 302-312

2.Catherine Thomas (2014). Meeting EFL Learners Halfway by Using Locally Relevant Authentic Materials. |Eglish Teaching Forum.Number

3.David L.Ch.\&Ulugbek Azizov (2019). Reconceptualizing Language Teaching. Baktria Press. Tashkent.

4. https://en.wikipedia.org/wiki/Grammar\%E2\%80\%93translation method

5.Spelleri, M. (2002) From lessons to life: Authentic materials bridge the gap. ESL Magazine 5 (2): 16-18.

6.Tomlinson B. (1998) V] Materials development in language teaching. Cambridge. UK. Cambridge University press.

7.X. Ibragimov (2019). Pedagogning innavatsion faoliyatini rivojlantirish.O'quv - uslubiy majmua. Tashkent. 